\title{
ANALISIS KELAYAKAN USAHA BUDI DAYA IKAN LELE UNIT PEMBENIHAN RAKYAT DARI ASPEK FINANSIAL
}

\author{
Leli Suwita ${ }^{1}$ Usmiar $^{2}$ \\ lelisuwita@gmail.com, usmiar@umsb.ac.id \\ Universitas Muhammadiyah Sumatera Barat
}

\begin{abstract}
The purpose of this research is to analyze the feasibility of catfish farming in the people's hatchery in the research area seen from the investment criteria, namely Net Present Value (NPV), Net Benefit and Cost Ratio (Net B / C Ratio), and, Payback Period (PBB).

Based on the results of the analysis, it shows that catfish farming in the people's hatchery is feasible to continue and operate properly, the financial aspect shows that the NVP value is more than zero, namely Rp. 67,904,660, the resulting Net B / C Ratio value is greater than one, namely 1.242, and Payback The period results in a shorter return on investment than the time to use the investment or in other words, $P P=2$ years 8,109 months. Thus, from the three methods of assessing the investment criteria for catfish farming, the community hatchery unit is feasible to continue its operations.
\end{abstract}

Key Words: business feasibility, financial aspects

Abstrak : Tujuan dari peneltian adalah Menganalisis kelayakan usaha budidaya ikan lele unit pembenihan rakyat di daerah penelitian dilihat dari kriteria investasi yaitu Net Present Value (NPV), Net Benefit and Cost Ratio (Net B/C Ratio), dan, Payback Period (PBB), .

Berdasarkam Hasil analisis menunjukkan bahwa budidaya ikan lele unit pembenihan rakyat layak untuk diteruskan dan beroperasi sebagai mestinya, Aspek Finansial menunjukkan nilai NVP lebih dari nol yaitu Rp.67.904.660, Nilai Net B/C Ratio yang dihasilkan lebihbesar dari satu yaitu 1,242, dan Payback Period menghasilan waktu pengembalian investasinya lebih pendek dari pada waktu penggunaan investasi atau denga kata lain PP $=2$ tahun 8,109 bulan. Dengan demikian dari ketiga metode penilaian kriteria investasi budidaya ikan lele unit pembenihan rakyat ini layak diteruskan operasionalnya.

Kata Kunci : present, benefit,payback,investasi

\section{A. PENDAhUluAN}

Indonesia merupakan Negara agraris yang sebahagian besar wilayahnya terdiri dari lahan pertanian dan sebagian besar penduduknya bermata pencaharian sebagai petani. Sektor perikanan terus dituntut berperan dalam perekonomian nasional melalui pembentukan Produk Domestik Bruto (PDB), perolehan devisa, penyediaan pangan dan bahan baku industri,pengentasan kemiskinan,penyediaan lapangan pekerjaan dan peningkatan pendapatan masyarakat.

Dalam rangka mengimbangi semakin pesatnya laju pertumbuhan penduduk Indonesia,makausaha perikanan yang maju perlu digalakkan di seluruh kawasan pertanian Indonesia.Dalam upaya membangun pertanian Indonesia agar kualitas dan kuantitas produk perikanan dapat ditingkatkan maka diperlukan peran pemerintah dalam hal kebijakan diversifikasi,intensifikasi,dan rehabilitasi lahan perikanan yang ada guna pencapaian pemerataan swasembada pangan.

Selama ini kegiatan budidaya lebih banyak dilakukan oleh pembudidaya skala kecil yang belum memiliki akses terhadap manajemen usaha,pasar dan permodalan.Dalam rangka pemerataan pembangunan,sektor budidaya perikanan dapat dijadikansalah satu sektor penggerak perekonomian.

Sektor perikanan merupakan salah satu komponen utama pembangunan ekonomi nasional yang tidak saja mampu memberikan kontribusi keluaran yang besar bagi 
perekonomian.tetapi juga mampu memberikan kontribusi yang besar dalam penyerapan tenaga kerja.Begitu pula dengan perekonomian di kota padang.

Pengembangan budidaya perikanan di Kota Padang perlu dikembangkan dengan serius dengan melakukan analisa-analisa, terutama analisa kelayakan dari segi finansial, sehingga keberlangsungan usaha dapat berjalan secara terus menerus

Berdasarkan uraian di atas maka peneliti akan melakukan analisa kelayakan terhadap usaha budidaya ikan lelepada budi Daya Ikan Lele Unit pembenihan Rakyat yang berlokasi di Jalan Makkah Kelurahan Koto Panjang Ikur Koto Kecamatan Koto Tangah Kota Padang

Permasalahan dalam penelitian ini adalah sebagai berikut, Bagaimana kelayakan usaha ikan Lele dilihat dari kriteria penilaian investasi, Net Present Value (NPV), Net Benefit and Cost Ratio (Net B/C Ratio), , dan Payback Period (PP),?

Rencana pemecahan masalah melalui penetapan investasi, menghitung aliran kas pertahun, selanjutnnya menganalisa kelayakan dengan metode kriteria investasi

Penelitian ini bertujuan untuk melihat kelayakan financial ikan lele dari kriteria investasi dalam melakukan ekspansi

\section{B. METODE PENELITIAN}

\section{a. Studi Kelayakan}

Suatu usaha dalam pelaksanaannya pada umumnya memerlukan dana yang cukup besar untuk keberlangsungan dan keberlanjutan usahanya, baik itu untuk proses produksi maupun investasi. Namun banyak usaha yang setelah dijalankan sekian lama ternyata tidak menguntungkan. Kegagalan tersebut dapat disebabkan kesalahan perencanaan, kesalahan dalam menaksir pasar, kesalahan dalam memperkirakan kontinuitas bahan baku dan sebagainya. Studi kelayakan merupakan kajian tentang proposal proyek atau gagasan usaha, yang objeknya mengenai pelbagai analisis terhadap perencanaan usaha, apakah usaha yang direncanakan akan sukses atau gagal apabila dilaksanakan (Dadang Husen Sobana 2018)

Untuk menentukan layak tidaknya suatu usaha dapat dilihat dari berbagai aspek. Setiap aspek untuk dapat dikatakan layak harus memiliki suatu standar nilai tertentu, namun keputusan penilaian tak hanya dilakukan pada salah satu aspek saja. Penilaian untuk menentukan kelayakan harus didasarkan kepada seluruh aspek yang akan dinilai Nantinya (Kasmir dan Jakfar 2012)

b. Investasi

Menurut Antony dan James S. Reece, dalam buku Dadang investasi adalah "The proposal is to invest fund, that is capital. At the present time in the expectation of earning return on this money over some future period."6 Investasi adalah modal yang ditanam sekarang atau saat ini yang diharapkan akan diterima kembali setelah beberapa tahun kemudian. Investasi meliputi semua dana (modal) yang tertanam di suatu perusahaan atau proyek, baik berupa harta lancar maupun harta tetap dalam jangka waktu lebih dari satu tahun.

Jenis InvestasiAda dua jenis investasi, yaitu investasi dalam aktiva lancar dan investasi dalam aktiva tetap. Pada aktiva lancar, investasi ditanamkan pada persediaan, piutang, atau aktiva lancar lainnya yang pengembaliannya diharapkan dapat diterima dalam waktu singkat, yaitu kurang atau sama dengan satu tahun. Adapun pada aktiva tetap, investasi ditanamkan pada gedung, tanah, mesin-mesin, kendaraan, dan alat-alat kantor yang pengembaliannya diharapkan dapat diterima dalam jangka waktu lebih dari satu tahun atau sesuai dengan umur investasi.

\section{Aktiva}

Aktiva adalah harta kekayaan perusahaan yang tidak terbatas pada yang berwujud, tetapi juga termasuk pengeluaran yang belum dialokasikan (charges) atau biaya yang masih harus dialokasikan pada penghasilan yang akan datang. Aktiva adalah 
sumber ekonomi yang dikuasai oleh perusahaan dan masih memberikan kemanfaatan pada masa yang akan datang. Ada beberapa bentuk aktiva, antara lain sebagai berikut.

a) Aktiva lancar meliputi kas dan sumber ekonomi lainnya, yang dapat dicairkan menjadi kas, dijual atau habis dipakai dalam rentang waktu satu atau selama satu siklus kegiatan normal perusahaan.

b) Aktiva tetap berwujud sumber ekonomi yang berwujud, yang perolehannya sudah dalam kondisi siap untuk dipakai atau dengan membangun terlebih dahulu.

c) Aktiva tetap tidak berwujud mencerminkan hak-hak istimewa atau kondisi yang menguntungkan perusahaan dalam mencapai pendapatan. Bagian aktiva tetap, yaitu sebagai berikut.

1) Tanah adalah bagian dari bumi yang dikuasai perusahaan, yang penggunaannya berkaitannya dengan pelaksanaan kegiatan normal perusahaan.

2) Gedung atau bangunan adalah bangunan milik perusahaan yang penggunaannya berkaitan dengan kegiatan normal perusahaan.

3) Mesin-mesin adalah segenap alat yang digunakan dalam pengolahan barang yang bermanfaat dalam kegiatan normal perusahaan.

4) Kendaraan adalah alat transportasi milik perusahaan yangdigunakan sebagai pengangkut barang dan karyawan.

5) Alat-alat perkantoran meliputi perangkat, perabot, dan perkakas perkantoran milik perusahaan yang digunakan dalam kegiatan normal perusahaan.

\section{Investasi dalam aktiva}

Investasi dalam aktiva dapat dibagi dalam dua aktiva, yaitu aktiva lancar dan aktiva tetap. Sifat kedua aktiva ini pada dasarnya sama, yang membedakan hanya proses pengembalian dana yang ditanam pada tiap-tiap aktiva tersebut. Contoh aktiva, yaitu bentuk inventori, piutang, dan lain-lain, sedangkan investasi dalam aktiva tetap pengembaliannya lebih dari satu tahun, bahkan lebih dari itu, yaitu sesuai dengan umur investasi tersebut. Investasi dalam aktiva adalah capital investment is a current cash outlay in the anticipation at benefits to be realised in the future.

c. Aspek Finansial

Aspek Finansial merupakan aspek yang digunakan untuk menilai keuangan perusahaan secara keseluruhan. Aspek ini sama pentingnya dengan aspek lainnya, bahkan ada beberapa pengusaha menganggap justru aspek inilah yang paling utama untuk dianalisis. Kajian aspek ini menggambarkan jelas hal-hal yang berkaitan dengan keuntungan perusahaan. Dengan demikian, aspek finansial merupakan salah satu aspek sangat penting untuk di teliti kelayakan nya. (Dedi dan Nurdin,2016)

Untuk itulah studi kelayakan suatu usaha menjadi sangat penting. Yang dimaksud dengan studi kelayakan bisnis atau sering pula disebut dengan studi kelayakan proyek adalah suatu penelitian tentang layak atau tidaknya suatu proyek bisnis yang biasanya merupakan proyek investasi itu dilaksanakan atau dengan kata lain segi aspek finansial.

Menurut Suryana, dalam buku Dadang aspek analisis keuangan meliputi komponen-komponen berikut:

1. Kebutuhan dana, yaitu kebutuhan dana untuk operasional perusahaan. 
2. Sumber dana, yaitu sumber dana internal dan modal eksternal.

3. Proyeksi neraca, sangat penting untuk mengetahui kekayaan perusahaan.

4. Proyeksi laba rugi, proyeksi laba rugi dari tahun ke tahun menggambarkan perkiraan laba atau rugi pada masa yang akan datang.

5. Proyeksi arus kas, dari arus kas dapat dilihat kemampuan perusahaan untuk membayar kewajiban keuangannya.

Secara keseluruhan penilaian dalam aspek keuangan meliputi :

1. Sumber-sumber dana.

2. Kebutuhan biaya investasi.

3. Estimasi pendapatan dan biaya investasi selama beberapa periode termasuk jenisjenis dan jumlah biaya yang dikeluarkan selama umur investasi.

4. Kriteria penilaian investasi.

5. Proyeksi neraca dan laporan laba/rugi untuk beberapa periode kedepan.

6. Rasio keuangan yang digunakan untuk menilai kemampuan perusahaan.

Alat ukur untuk menentukan kelayakan suatu usaha berdasarkan kriteria investasi dapat dilakukan melalui pendekatan Payback Period (PP), Average Rate of Return (ARR), Ner Present Value (NPV), Internal Rate Of Return (IRR), Profitability Index (PI), dan Break Even Point (BEP)

Paling tidak ada lima tujuan mengapa perlu adanya studi kelayakan bisnis sebelum usaha dilakukan (Kasmir dan Jakfar,2012) yaitu :

a. Menghindari Resiko Kerugian.

Untuk menguasai resiko di masa yang akan datang ada semacam kondisi kepastian. Kondisi ini ada yang dapt diramalkan akan terjadi atau memang dengan sendirinya terjadi tanpa dapat diramalkan. Dalam hal ini berfungsi studi kelayakan adalah untuk meminimalkan resiko yang tidak kita inginkan, baik resiko yang dapat kita kendalikan maupun yang tidak kita inginkan, baik resiko yang dapat kita kendalikan maupun yang tidak dapat dikendalikan.

b. Memudahkan Perencanaan.

Perencanaan akan lebih mudah jika kita sudah dapat meramalkan apa yang akan terjadi dimasa yang akan datang, maka akan mempermudah kita dalam melakukan perencanaan dan hal-hal apa saja yang perlu direncanakan.

c. Memudahkan pelaksanaan pekerjaan.

Dengan adanya berbagai rencana yang sudah disusun akan sangat memudahkan pelaksanaan pekerjaan. Para pelaksana yang mengerjakan bisnis tersebut telah memiliki pedoman yang harus diikuti. Pedoman tersebut telah tersusun secara sistematis, sehingga usaha yang dilaksanakan dapat tepat sasaran dan sesuai dengan rencana yang sudah tersusun.

d. Memudahkan pengawasan.

Dengan telah dilaksanakannya suatu usaha sesuai dengan rencana yang sudah disusun, maka akan memudahkan kita untuk melakukan pengawasan terhadap jalannya usaha. Pengawasan ini perlu dilakukan agar tidak melenceng dari rencana yang telah disusun.

e. Memudahkan pengendalian.

Apabila dalam pelaksanaan pekerjaan telah dilakukan pengawasan, maka jika terjadi penyimpangan akan mudah terdeteksi, sehingga dapat dilakukan pengendalian atas penyimpangan tersebut. Tujuan pengendalian adalah untuk mengendalikan pelaksanaan agar tidak melenceng dari rel yang sesungguhnya, sehingga pada akhirnya tujuan perusahaan akan tercapai. 
Dalam penelitian ini metode pengumpulkan data yang digunakan adalah dokumentasi yaitu pengumpulan data berupa laporan keuangan dan dokumen-dokumen yang berkaitan dengan penelitian yang bersumber dari bagian keuangan tempat penelitian.

Teknik analisa data yang digunakan dalam penelitian ini adalah penilaian keriteria investasi yaitu:

a. $\quad$ Net Present Value (NPV)

Net Present Value (NPV) dari suatu proyek merupakan nilai sekarang(Present Value) dari selisih antara Benefit (manfaat) dengan Cost(biaya) pada Discount Rate tertentu. Net Present Value (NPV)menunjukkan kelebihan benefit (manfaat) dibandingkan dengan $\operatorname{Cost}$ (biaya).

Jika Present Value benefitnya lebih besar dari present value biaya,berarti proyek tersebut layak atau menguntungkan. Dengan perkataanlain, apabila NPV > 0 berarti proyek tersebut menguntungkan.Sebaliknya jika NPV $<0$ berarti proyek tersebut tidak layakdiusahakan.Net Present Value merupakan metode penilaian kriteria investasi yang paling sering digunakan. Rumus perhitungan NPV menurut Jumingan (2009:81) adalah:

$$
\mathrm{NPV}=\sum_{\mathrm{t}=0}^{\mathrm{n}} \frac{\mathrm{At}}{(1+\mathrm{K})^{\mathrm{t}}}
$$

Keterangan:

$$
\begin{aligned}
& \text { At }=\text { aliran kas masuk pada periode } \mathrm{t} \\
& \mathrm{k}=\text { discount factor } \\
& \mathrm{n}=\text { periode terakhir aliran kas yang diharapkan }
\end{aligned}
$$

b. Profitability Index (PI)/Benefit Cost Ratio (BCR)

Metode Profitability Index (PI) Menurut Syamsuddin (2011:453) "Metode Profitability Index biasa disebut juga dengan istilah B/C Ratio, pendekatan ini hampir sama dengan metode NPV hanya saja PI mengukur present value untuk setiap rupiah yang diinvestasikan, sedangkan teknik perhitungan PI adalah sbb :"

$$
\text { PI }=\frac{\text { Present Value Cash FLow }}{\text { Present Value Intial Investment }}
$$

c. Payback Period (PP)

Metode Payback Period merupakan teknik penilaian terhadap jangka waktu (periode) yang dibutuhkan untuk menutup initial investment dari suatu proyek dengan menggunakan cash inflow yang dihasilkan proyek tersebut. Jika aliran kas tidak sama maka harus dicari satu persatu yakni dengan cara mengurangkan total investasi dengan cash flow-nya sampai diperoleh hasil total investasi sama dengan cashflow pada tahun tertentu (Syamsuddin, 2011)

Pay Back Period merupakan jangka waktu tertentu yang menunjukkan terjadinya arus penerimaan (Cash In Flows) secara kumulatif sama dengan jumlah investasi dalam bentuk present value.

Dapat di gambarkan dengan :

$$
\mathbf{P P}=\frac{\text { Nilai Investasi }}{\text { Kas Masuk Bersih/tahun }} \times 1 \text { Tahun }
$$




\section{HASIL DAN PEMBAHASAN}

a. Analisis Net Present Value (NPV)

Pada metode ini terlebih dahulu perlu ditentukan nilai sekarang (Present Value) dari cash flows pada masa - masa mendatang dan nilai sekarang dari investasi awal. Untuk perhitungan Net Presen Value dapat dilihat pada Tabel berikut:

\section{Tabel 1}

Present Value proyeksi arus kas masuk proyek investasi produksi Budidaya ikan Lele Unit pembenihan rakyat

\begin{tabular}{|c|c|c|c|}
\hline Tahun & $\operatorname{Cf}(\mathbf{R p})$ & Df $(0,12)$ & $\begin{array}{c}\text { PV.CF } \\
\text { (Rp) }\end{array}$ \\
\hline 1 & 94.630 .000 & 0,893 & 84.522 .450 \\
\hline 2 & 94.510 .000 & 0,797 & 65.589 .940 \\
\hline 3 & 134.450 .000 & 0,712 & 95.728 .400 \\
\hline \multirow[t]{4}{*}{4} & 145.200 .000 & 0,636 & 92.347 .200 \\
\hline & & Total PV. CF & 347.904 .660 \\
\hline & & PV. Investasi & 280.000 .000 \\
\hline & & NPV & 67.904 .660 \\
\hline
\end{tabular}

Sumber: Data diolah sendiri

Dengan investasi sebesar Rp. 280.000.000 serta total Present Value sebesar Rp.347.904.660,dengan menghasilkan Net Present Value nya sebesar Rp. 67.904.660. Hasil ini memperlihatkan bahwa nilai NPV lebih besar dari nol (0), berarti budi daya ikan lele unit pembenihan rakyat ini layak diterima atau menguntungkan.

b. Analisis Payback Periode (PP),

Pay Back Period merupakan jangka waktu tertentu yang menunjukkan terjadinya arus penerimaan (Cash in Flows) secara kumulatif sama dengan jumlah invetasi dalam bantuk present value.

$$
\frac{\text { Jumlah investasi }}{\text { Masuk Bersih/ tahun }} \times \text { tahun }
$$

Dalam hal ini karena aliran kas per tahunnya tidak sama, maka perhitungan PP adalah sebagai berikut:

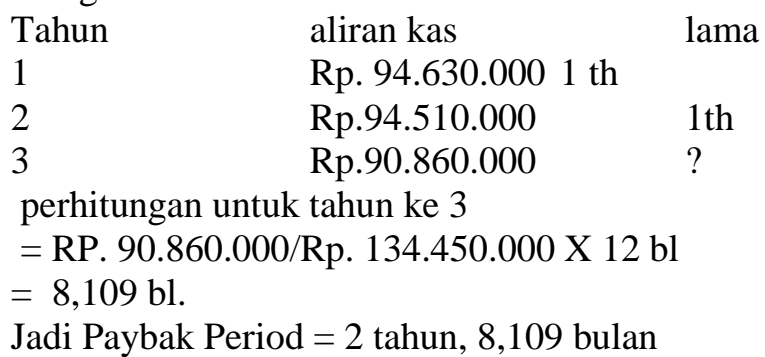

Dari penghitungan di atas dapat dilihat dengan aliran kas pertahun nya untuk menutupi investasi sebesar Rp. 28.000.000,- menghasil Paybak Period selama 2 tahun 8,109 bulan, berarti waktu pengembalian investasinya lebih pendek dari pada waktu penggunaan investasi dan memaknai bahwa budidaya ikan Lele unit pembenihan rakyat layak untuk jalankan.

\section{c. AnalisisProfitability index (PI)/Benefit Cost Ratio (BCR)}

Pada metode ini di cari suatu angka indeks dengan membandingkan antara benefit (penerimaan) dengan cost (biaya). Benefit dan biaya dimasudkan juga dalam bentuk nilai sekarang (present value). berikut perhitungan Benefit Cost Ratio :

$$
\frac{\text { Total PV CF }}{\text { PV. Investasi }}=\frac{347.904 .660}{280.000 .000} \times 1=1,242
$$


Dari hasil perhitungan diatas Benefit cost rasio $>1$, maka benefit dari budidaya ikan Lele tersebut lebih besar dari pada pengeluaran yang dibutuhkan untuk pembenihan budidaya ikan Lele, berarti budidaya ikan lele unit pembenihan rakyat layak atau menguntungkan.

\section{KESIMPULAN}

Dari penelitian ini dapat disimpulkan bahwa kelayakan finansial usaha budidaya ikan Lele unit pembenihan rakyat dilihat dari finansial dengan metode kriteria investasi:

Net Present Value (NPV), penilain investasi yang berdasarkan pada selisih antara aliran kas yang dinilai sekarangkan dengan investasi awal yang dinilai sekarang menghasilkan NPV nya lebih besar dari nol (()) maka usaha budidaya ikan lele unit pembenihan rakyat ini layak untuk di jalankan atau dengan kata lain menguntungkan.

Profitability Index (PI) Net Benefit and Cost Ratio (Net B/C Ratio), penilian investasi yang berdasarkan hanya membandingkan antara aliran kas yang telah dinilai sekarangkan dengan investasi yang telah dinilai sekarangkan menghasil PI lebih besar dari satu (1) maka usaha budidaya ikan lele unit pembenihan rakyat ini layak untuk dijalankan.

Payback Period (PP), penilai investasi yang melihat lama waktu pengembalian investasi dari aliran kas yang telah dinilai sekarangkan menghasil lebih pendek dari waktu pengusulan investasi, maka usaha budidaya ikan lele unit pembenihan rakyat ini layak atau menguntung untuk dijalankan

\section{E. DAFTAR PUSTAKA}

Dadang Husen Sobana, (2018) Studi Kelayakan bisnis, Pustaka Setia Bandung Hidayat, Nurdin dan Purwana Dedi, (2016) Studi Kelayakan Bisnis Raja Grafindo Ibrahim Yacob.(2009) Studi Kelayakan Bisnis, Jakarta : Rineka Cipta

Jumingan, 2009. Studi Kelayakan Bisnis. Jakarta: Bumi Aksara

Kasmir dan Jakfar.2012. Studi Kelayakan Bisnis, Jakarta Kencana

Syamsuddin, Lukman. 2011. Manajemen Keuangan Perusahaan. Jakarta: CV Rajawali 